the Royal Flying Corps as an observer, being shot down and taken prisoner in 1918. There were few at that time who foresaw the special contributions that aerial survey could make to archæological studies, but Crawford's field-work on the chalk downs had shown him the use of shadows in studying complicated earthworks, and his war-time flying experience impressed upon him the value of the aerial view for the understanding of archæological sites.

At the time of the First World War archæological posts were few and offered little prospect of a career, but Crawford's appointment in 1920, as the first archæology officer at the Ordnance Survey, provided just the opening he needed. Until the time of his appointment, the archæological information embodied in Ordnance maps was largely in the hands of the field staff, who might have little knowledge of archæology, no matter how competent they were at surveying. The task confronting Crawford was immense; however, he found time not only for routine revision of archæological detail on the Ordnance maps, but also for the preparation of a series of 'period' maps, of which that of Roman Britain was the first and best known. The value of this work at the Ordnance Survey, undertaken with a minimum of assistance, may be seen in the official large-scale maps of the United Kingdom, which attain a standard in archæoological cartography scarcely approached elsewhere. The results of Crawford's field surveys were published as individual papers or larger works, such as "The Long Barrows of the Cotswolds" (1925), an important account of a selected class of monuments.

It is probably as the pioneer of archæological air photography and as the founder-editor of the quarterly journal Antiquity that Crawford will best be remembered. His achievement in the first sphere culminated in the publication, with Alexander Keiller, of "Wessex from the Air" (1928), a splendidly illustrated account of an archæological air reconnaissance of Salisbury Plain and adjacent aroas, which sets a new standard in archæological research. In 1928, Crawford visited the Middle East, in an attempt to secure the preservation of air photographs taken by the Royal Air Force, and to direct attention to the unique possibilities open to air photography for research in that region. He was evor keen to foster the development of the subject in Britain, either publishing discoveries himself or making known the work of others in the same field. Much of his lator work appeared in Antiquity, over which he took great pains, making several spocial journeys to Europe and North Africa. If the first dozen years of that journal represent its best period, it has always provided a forum for review and criticism and for exchange of ideas on all branches of archæology.

As an archæologist Crawford had a flair for field survey, which served him well when studying earthworks, either on the ground or from the air. He was a marked individualist, gifted with considerable powers of expression, to which the pages of Antiquity bear witness. For such a person, relations in an official department cannot always have boen oasy, but he had a great capacity for friendship, and was able to awake in others something of his own immense enthusiasm for his chosen subject. He was created C.B.E. in 1950, elected Fellow of the British Academy in 1949 and awarded honorary degrees by the Universities of Cambridge and Southampton.

J. K. S. ST, JoSEPH

\section{Prof. W. J. Jongmans}

THe sudden death of Prof. Jongmans, at Hoerlen on October 13, robs the world of one of its most active palæobotanists. Willem Josephus Jongmans was born on August 13, 1878, at Leyden, where he received his early education. A student of the University of Leyden and later of the University of Munich, he was awarded a D.Phil. of the latter University in 1906. In the same year he was eharged with palæobotanical research in one of the Dutch Government Services concerned with fuel resources, and the following year, 1907, was appointed a curator at the Rijksherbarium in Leyden. In 1919 he was released from the post at the Herbarium to become head of one of the departments in the Government Geological Service. While holding this position Jongmans was nominated head of the office at Heerlen, which led directly to his appointment as director of the Geological Bureau of the Netherlands Mining District at Heerlen, a post which he held from 1924 until his retirement in 1946. In addition to being director of the Bureau he was, from 1932 onwards, extraordinary professor of palæophytology in the University of Groningen.

Throughout his career, Jongmans's interest was directed towards the study of the flora of the Carboniferous period, and his extensive knowledge led to the publication of many authoritative papers on the plants from such widely distant places as Limburg and Sumatra, North America and Anatolia, Peru and Egypt, Spain and the U.S.S.R. But perhaps he is best remembered in Britain for the excellent "Monograph of the Calamites of Western Europe", written in collaboration with Kidston (1915-17), and the monumental "Fossilium Catalogus", published in twenty-two parts between 1913 and 1937. Jongmans's interest was not, however, confined purely to the plants, but extended over the floral assemblages of which they had been members. Early in his life he made a specialist study of the stratigraphic relations of the Carboniferous floras and he was responsible for many publications on this aspect of palæobotany. We should remember also his very important opinions on the nomenclature of fossil plants.

Though he officially retired in 1946, Jongmans carried on active research until the very last, and he was often to be seen in the Geological Bureau, which was only a short distance from his home at Heerlen. Time was always found to welcome and encourage a visiting palæobotanist who had come to see the magnificent collections and discuss problems with the master who had done so much for the furtherance of his subject. In recognition of his services to his country and science, Jongmans had been elected an Officer in the Order of Orange-Nassau and a Knight of the Order of the Nethorlands Lion.

Atan Wesley

\section{Mr. C. T. Gimingham, O.B.E.}

Through we death of Conrad Theodore Giming. ham on November 16, agricultural entomologists and plant pathologists have lost one of their pioneers and dearest friends.

Gimingham joined the staff of the Ministry of Agriculture's Plant Pathology Laboratory at Harpenden, as entomologist in 1928 , at a most important time in the development of agricultural entomology. The specialist biological advisory services in agriculture had started some years earlier when several young and enthusiastic biologists were stationed at 
universities and agricultural colleges to investigate local problems and give advice to farmers. The Plant Pathology Laboratory acted as their coordinating link, and Gimingham came into very close touch with all the advisory entomologists. In 1944 he succeeded the late Sir John Fryer as director of the Laboratory and as chairman of the Conference of Advisory Entomologists, with which he had been closely associated since his appointment. It was one of his great delights, and although he relinquished his chairmanship shortly after his retirement, he remained a member until his death. The modern developments in the insecticide field, with which Gimingham had much to do, started in the 1920's, and he proved to be an ideal person to guide the biologists who had become available, to see that the best use was made of the new materials provided by research and industry.

In the late 1930's it became evident that there was 2 real need to institute some form of approval scheme for crop-protection chemicals. It was largely through Gimingham's ability for painstaking negotiation and the deep respect in which he was held by both sides that in 1942 the Ministry and the Association of British Insecticide Manufacturers instituted the voluntary Crop Protection Products Approval Scheme. The success of this venture bears testimony to his achievement.

He was deeply occupied in phytosanitary work at home and in Europe, for example, with the Colorado beetle, and he must be given a good deal of the credit for preventing this pest from becoming esteb. lished in Great Britain after the Second World War.

Perhaps Gimingham's greatest influence lay in his keen interest in the development of the younger entomologists. His quiet modesty, kindliness and sincerity made him the ideal guide, philosopher and friend. We were happy and privileged to place our trust in him, and many of us are thankful for his help.

Gimingham was closely associated with the Royal Entomological Society and the Association of Applied Biologists, of which he was president during 1938-40.

He married, in 1912, Muriel Blake, who survives him together with two sons and a daughter.

F. H. JACOB

\section{NEWS and VIEWS}

\section{Rothamsted Experimental Station :}

Sir William Ogg

THE retirement of Sir William G. Ogg from the directorship of the Rothamsted Experimental Station is announced to take place next September. He succeeded Sir John Russell in 1943, having previously been director of the Macaulay Institute for Soil Research, near Aberdeen. At Rothamsted he continued the expansion begun in the inter-war period, and successfully organized the inclusion of the Soil Survey of England and Wales previously directed by the late Prof. G. W. Robinson, of Bangor, bringing Dr. A. Muir from Aberdeen as the new head. As the owner and manager of a well-known farm in Aberdeenshire, Sir William has had exceptional opportunities of appreciating the new, and often difficult, agricultural problems of the post-war period and the ways in which modern science could contribute to their solution. His genial approachability has given him considerable popularity in agricultural circles, and on a variety of occasions he has been asked to undertake official visits overseas to advise on problems where his knowledge and shrewd judgment proved very helpful. His friendly relations with the Rothamsted staff enabled the expansion of the various departments to proceed smoothly, and when the Station finally obtained vacant possession of the attractive old manor house, which had been acquired with the estate in 1934, he had it converted into a hostel, thereby providing living quarters for some of the staff, as well as additional accommodation for conferences and other gatherings. His useful term as president of the Society of Chemical Industry will long be remembered. It is understood that he will retire to his farm, where all his friends and former colleagues will wish him and Lady Ogg many happy years of useful activity.

Mr. F. C. Bawden, F.R.S.

Mr. F. C. Bawden, head of the Plant Pathology Department of the Rothamsted Experimental Station, has been appointed director of the Station in suc. cession to Sir William Ogg. Mr. Bawden, who is forty-nine, is well known for his brilliant researches on the virus diseases of plents, for which he was elected a Fellow of the Royal Society in 1949. His appointment shows the growing importance of plant pathology in Great Britain : the directorship has hitherto been from the side of soil and plant nutrition, the original, and for long the main, subject of the Rothamsted investigations. After a distinguished career at Cambridge, he went to Rothamsted in 1936 as physiologist to the Virus Disease Unit and soon attracted attention by identifying, in conjunction with his biochemical colleague, N. W. Pirie, a number of plant viruses and virus strains as nucleoproteins. They isolated in crystalline form the tomato bushy stunt virus, the first ever to be so obtained. With another colleague, A. Kleczkowski, much valuable work has been done on the serology of the viruses. New methods have been discovered of inactivating viruses without destroying their antigenicity. Mr. Bawden has also organized much valuable field work to discover the factors affecting the rate of spread of virus diseases, in the hope of finding messures of control. He has shown that he not only possesses high scientific ability and power of organization, but also that he can appreciate scientific merit in others. Under his direction, Rothamsted may confidently be expected to maintain the high position it has hitherto held among the world's institutes for the development of agricultural science.

Ministry of Agriculture, Fisheries and Food ; Fishery Research : Mr. G. M. Graham, C.M.G., O.B.E.

Tre Ministry of Agriculture, Fisheries and Food has announced the retirement on February 21 of Mr. G. M. Graham, director of Fishery Research. Mr. Graham has served on the Ministry's staff for thirty-eight years, having joined the staff of the Lowestoft laboratory in 1920. In his earlier years, Mr. Graham was especially concerned with research 